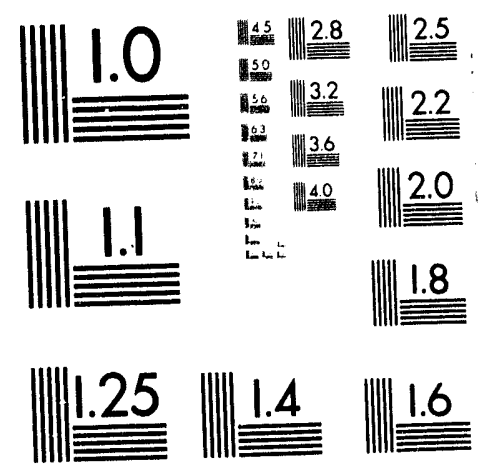




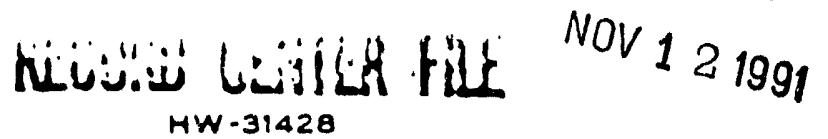

TECHNOLOGY-HANFORD PROCESSES

COPY NO.

ion 1 of 1 .

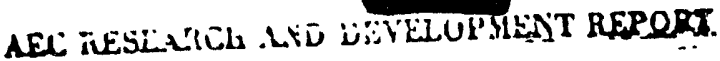

\section{EVALUATION OF NICKEL FERROCYANIDE SCAVENGING OF URANIUM RECOVERY PLANT SOLVENT EXTRACTION WASTE}

BY

M. J. STEDWELL

TECHNICAL SECTION

ENGINEERING DEPARTMENT

MARCH 22, 1954

DISCLAIMER

This report was prepared as an account of work sponsored by an agency of the United States Government. Neither the United States Government nor any agency thereof, nor any of their employees, makes any warranty, express or implied, or assumes any legal liability or responsi-I bility for the accuracy, completeness, or usefulness of any information, apparatus, product, or $(2,1)$ process disclosed, or represents that its use would not infringe privately owned rights. Refer-
ence herein to any specific commercial product, process, or service by trade name, trademark, manufacturer, or otherwise does not necessarily constitute or imply its endorsement, recommendation, or favoring by the United States Government or any agency thereof. The views and opinions of authors expressed herein do not necessarily state or reflect those of the -7 United States Government or any agency thereof.

\section{HANFORD ATOMIC PRODUCTS OPERATION}

RICHLAND. WASHINGTON

\section{GENERAL ELECTRIC}

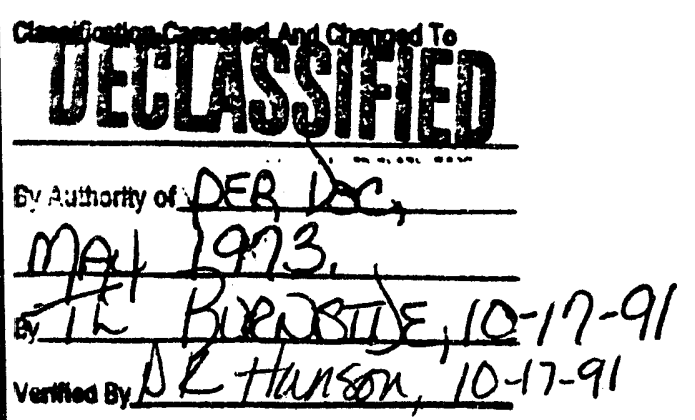

MATE

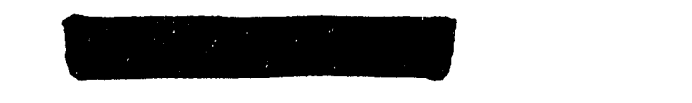


$\mathrm{HW}-31428$

Technology - Hanford. Processes

This document fonsïsts

of 11 pages dopy

of Se copies. Series

Copt 1 of 1 .

EVALUATION OF NICKEL FERROCYANIDE SCAVENGING OF

\section{URANIUM RECOVERY PLANT}

-

SOLVENT EXTRACTION WASTE

$\circ$

By

$\bullet$

M. J. Stedwell

Plant Processes Unit

Separations Technology Sub-Section

March 22, 1954

\section{HANFORD ATOMIC PRODUCTS OPERATION}

- $\cdots \cdots$ RICHLAND, - WASHINGTON

Operated for the Atomic Energy Commission by the

General Electric Company under Contract W-31-109-Eng-52

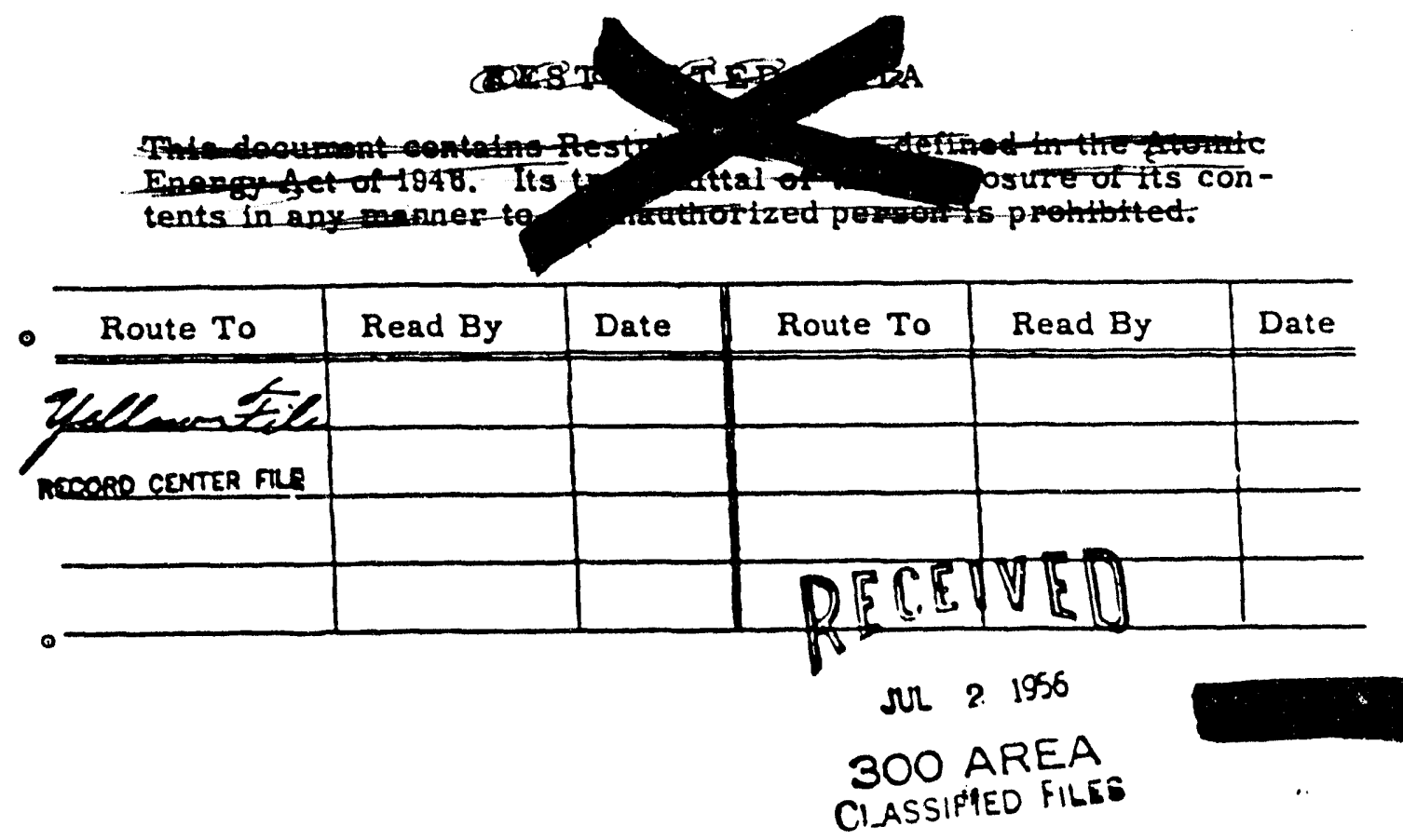




$$
\begin{gathered}
\text {-2- } \\
\text { Technology - Hanford Processes }
\end{gathered}
$$

\section{INTERNAL DISTRIBUTION}

\section{Copy Number}

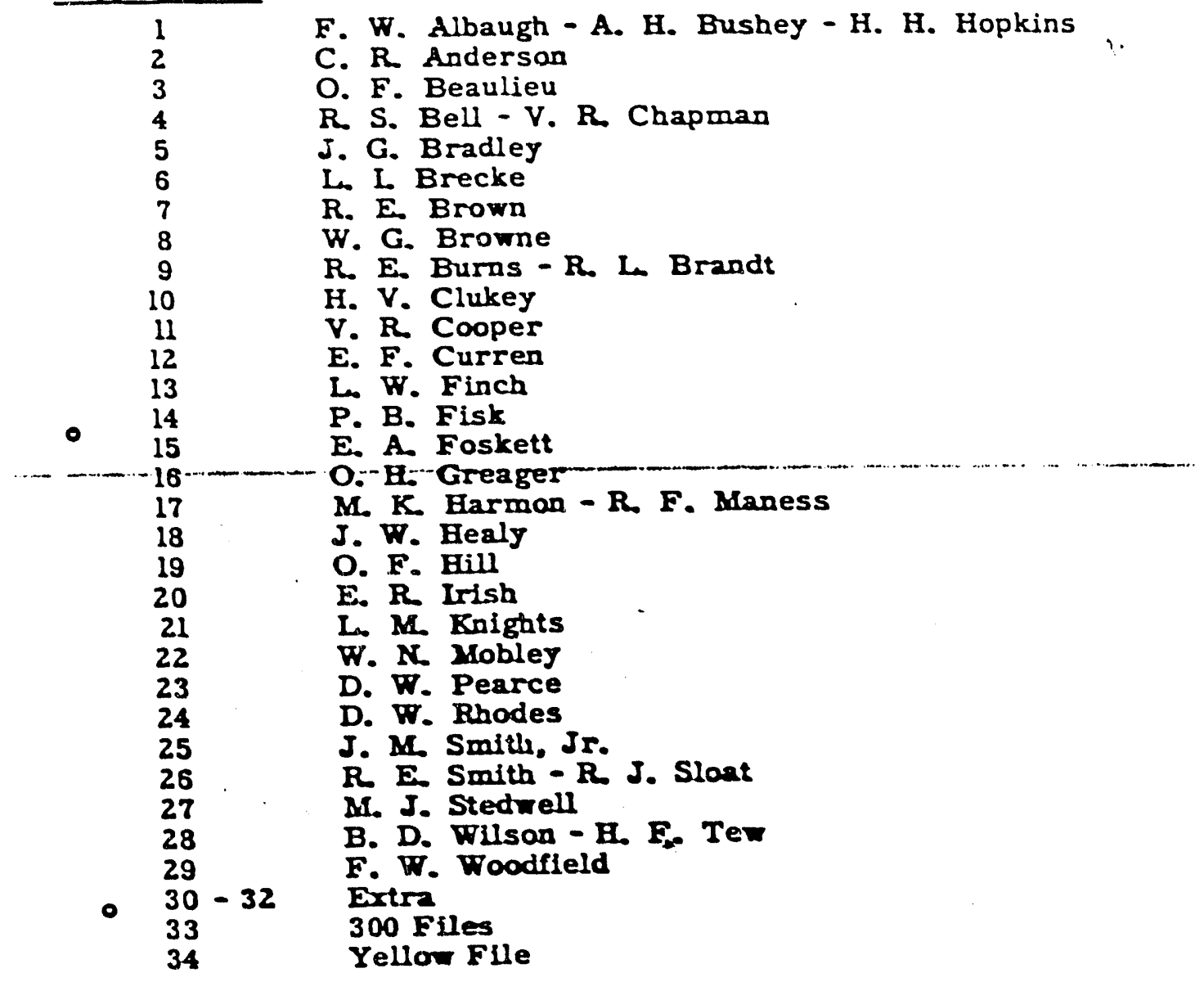

○

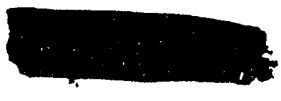




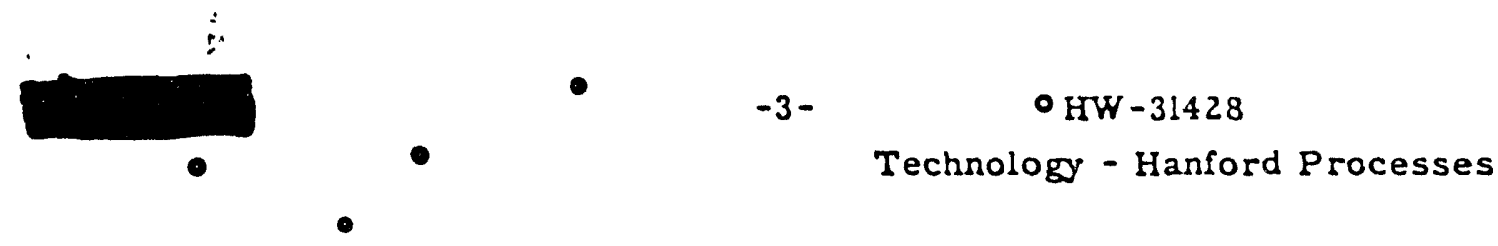

\section{EXTERNAL DISTRIBUTION}

Copy Number

35

$36-37$

38

$39-43$

44

45

46

$47-50$

51

$52-66$
Armed Forces Special Weapons Project, Washington Atomic Energy Commission, Washington

Chicago Patent Group

duPant Company, Augusta

duPont Ccmpany. Wilmington

Hanford Operations Office

Hanford Operations Office, Attn: J. I. Thomas

Knolls Atomic Power Laboratory

Patent Branch, Washington

Technical Information Service, Oak Ridge 


\section{INTRODUCTION}

The Uranium Recovery Plant, over the life of the operation, will aqueous waste in a volume equivalent to the volume of stored uranium waste which, after acidification, constitutes the feed stream for the process. Due to variations in the composition of the feed stream, the waste stream does not consistently have a volume equivalent to the volume of the stored metal waste. This variation in volume equivalence impedes tank farm scheduling because of the necessity for return of the process waste to underground tanks made available by the recovery operations.

More Important to the long range Hanford Atomic Products Operation economics is the use of underground storage, with initial custs of approximately 35 to 45 cents per gallon and current replacemeat casts of 22 cents per gallon, for these comparatively moderate radioactive Uranium Recovery Plant wastes. A means of removing the long-lived fission products has been the objective of investigations conducted by the Applied Research Sub-Section, since studies conducted by the Radiological Sclences Departme st incicate that lang-lived $\mathrm{Cs}-137$ and $\mathrm{Sr}_{\mathrm{r}}-90$ are the isotopes which could $=$ igrate and enter the biological cycle via underground water movement.

A plant test, using nickel ferrocyanide to remove $\mathrm{Cs}-137$ and $\mathrm{Sr}-90$ from the Uranium Recovery Plant wastes, as proposed in HW-29383, (1) has been completed and this memorandum has been prepared to summarize and report the results oiviuined from this test. 


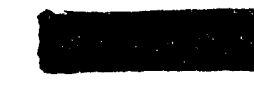

\section{$\cdot \bullet$}

$-5-$

$\mathrm{HW}-31428$

- SUMMARY AND CONCLUSIONS

Removal of $\mathrm{Cs}-137$ and Sr-90 from the Uranium Recovery Plant solvent extraction wastes (combined RAW -ROW) jy scavenging on a precipitate of nickel ferrocyanide $\left[\mathrm{Ni}_{2} \mathrm{Fe}(\mathrm{CN})_{6} \cdot \mathrm{X} \mathrm{H}_{2} \mathrm{O}\right]$ was demonstrated by the plant test to attain a 420 to 10,000 and 40 to 200 fold decontamination for cesium and strontium, respectively, provided the $\mathrm{pH}$ of the neutralized waste was controlled within the range of 8 to 10. It is expected that scavenging of the plant solvent extraction wastes could routinely attain at least a 400 fold and probably greater decontamination of cesium and about a 40 fold decontamination of strontium.

Evaluation of the soll conditions, following the cribbing of about 250,000 gallons of scavenged waste and other parallel soil column studies allowed the Earth Sciences group of the Biophysics Section to conclude that up to 6,000 gallons of neutralized, scavenged, unconcentrated, settled solvent extraction waste supernate per square foot of crib bottom surface area, could be routinely cribbed. (3)

During the test, approximately $\varepsilon, 500$ gallons of solvent extraction waste per ton of uranium processed was scavenged with about 93 pounds of $\mathrm{Ni}_{2} \mathrm{SO}_{4} \cdot 6 \mathrm{H}_{2} \mathrm{O}$ and 149 pounds of $\mathrm{K}_{4} \mathrm{Fe}(\mathrm{CN})_{6} \cdot 3 \mathrm{H}_{2} \mathrm{O}$. The volume of precipitate obtained in Tank $101-T$ was ahout 600 gallons per ton of uranium processed or about seven volume per cent of the waste.

A net saving of about $\$ 500$ per ton of uranium processed can be attained through reduction of underground storage volume $(\$ 530)$, and elimination of steam required for two-stage evaporation $(\$ 40)$, by the experiditure of approxdmately $\$ 70$ for scavenging chemicals.

\section{DISCUSSION OF THE TEST}

In October, 1953, approximately 500,000 gallons of Uranium Recovery Plant solvent extraction waste, produced during the processing of approximately 60 tons of uranium, were scavenged with nickel ferrocyanide by the procedure presented in HW-29383. (1) The scavenged waste 


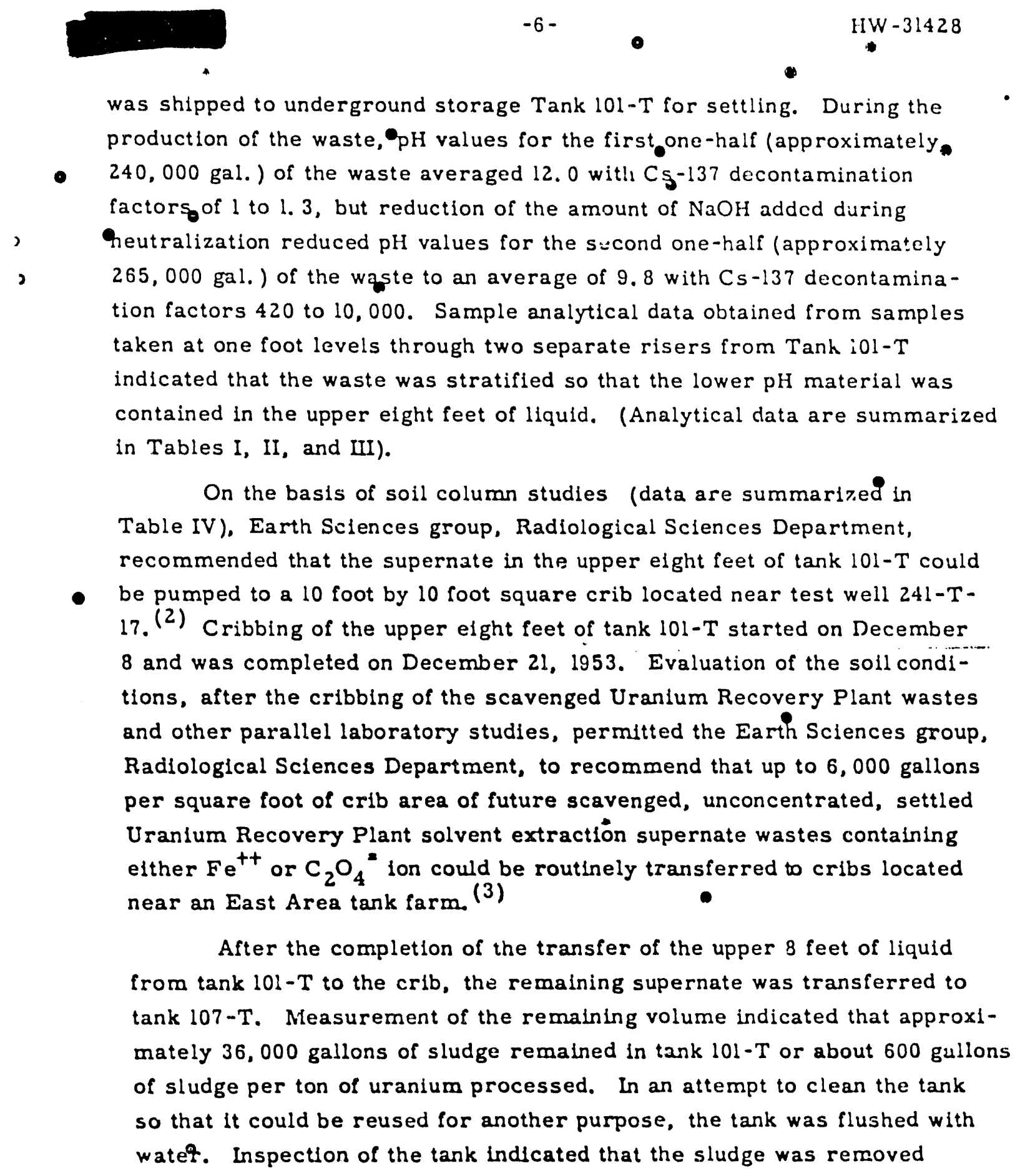

On the basis of soil column studies (data are summarized in Table IV), Earth Sclences group, Radiological Sciences Department, recommended that the supernate in the upper elght feet of tank 101-T could be pumped to a 10 loot by 10 loot square crib located near test well $241-T$ 17. (2) Cribbing of the upper elght feet of tank 101-T started on December 8 and was completed on December 21, 1953. Evaluation of the soll cond1tions, after the cribbing of the scavenged Uranlum Recovery Plant wastes and other parallel laboratory studies, permitted the Earth Sciences group, Radiological Sclences Department, to recommend that up to 6,000 gallons per square foot of crib area of future scavenged, unconcentrated, settled Uranlum Recovery Plant solvent extraction supernate wastes containing either $\mathrm{Fe}^{++}$or $\mathrm{C}_{2} \mathrm{O}_{4}$ " in could be routinely transferred to cribs located near an East Area tank farm. (3)

After the completion of the transfer of the upper 8 feet of liquid from tank $101-T$ to the $\mathrm{cr} / \mathrm{b}$, the remaining supernate was transferred to tank 107-T. Measurement of the remaining volume indicated that approximately 36,000 gallons of sludge remained in tank $101-\mathrm{T}$ or about 600 gullons of sludge per ton of uranium processed. In an attempt to clean the tank watef. Inspection of the tank indicated that the sludge was removed

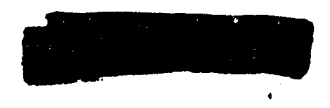




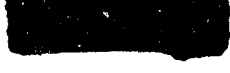

\%

from a wide path leading from the risers where the water was added to the heel jet, but large quantities of sludge remain over the surface where the water did not reagh it. $\mathrm{pH}$ CONTROL

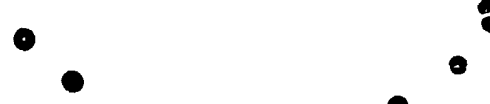

In the Uranium Recovery Plant, the $\mathrm{pH}$ of the neutralizer is measured and recorded on a continuous basis by a pHbelectrode inserted in a continuous sampler cell. Since the plant startup in November, 1952, - the $\mathrm{pH}$ sampler has frequantly plugged and then given erroneous $\mathrm{pH}$ values until the sampler is flushed and returned to a normal service. During the first portion of this tesi, the above conditions existed and resulted in the inadvertent over-neutrallzation of about 240,000 gallons of the scavenged waste. Duringahe last one-half of the test, samples yere frequently tested with $\mathrm{pH}$ paper and the caustic addition rate was adjusted to control the $\mathrm{pH}$ in the range of 8 to 10 .

After the completion of the scavenging test, the Instrument

- Development group, Chemistry Unit, modified the $\mathrm{pH}$ sampler unit by the addition of a periodic (every $10 \mathrm{~min}$.) dilute phosphoric acid flush. This modification has essentially eliminated the difficulties encountered with the pH monitor. Samples analyzed by the laboratory agree fairly well with the recorded $\mathrm{pH}$ values. It is expected that this modification will be sufficient to insure that the $\mathrm{pH}$ during routine scavenging can be controlled within the range of 8 to 10 .

\section{COST CONSIDERATIONS}

$\circ$

- During the test, approximately 506, 000 gallons of unconcentrated scavenged waste was produced during the processing of about 60 tons of

- uranium or 8,500 gallons of waste per ton of uranium. From this waste approximately 36,000 gallons of settled sludge was obtained or approximately 600 gallons of sludge per ton of uranium.

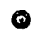

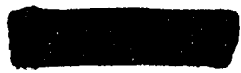




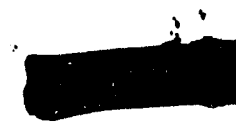

•

$$
-8-
$$

-
$11 W-31428$

○

For comparison, costs for the current and scavenging processes eare summarized below:

•

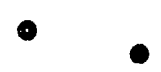

Cosi of storage space/Ton U

Cost of Chemicals bTon U

\section{Total Cost/Ton U}

Volume of stored waste/Ton $U$

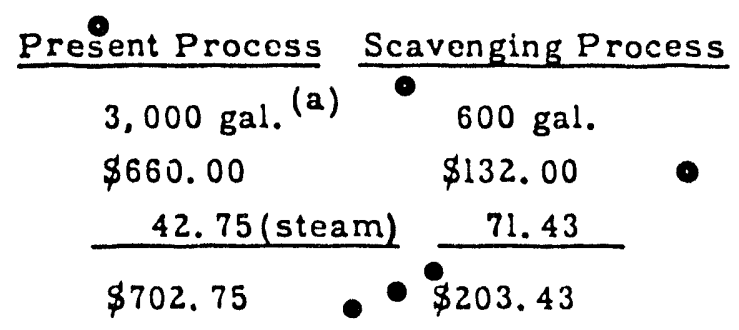

(a) The waste is rouingely evaporated from 8,500 to 3,000 gallons per ton of uranium by two stages, 1) the UR Plant primary waste evaporators and 2) the $\mathrm{BIPO}_{4}$ first cycle evaporators.

From the above summary. It may be noted that storage space valued at about $\$ 530$ may be saved by the expenditure of only $\$ 29$ additional for chemicals in place of steam (Note: Cost of labor for the two processes is assumed to be equal).

FUTURE WORK

\section{-}

Studles for the possible future scavenging and cribbing of currently - stored cancentrated Uranlum Recovery and Seevaporated Uranium Recovery and Bismuth Phosphate llrst-cycle wastes are in progress.

\section{ACKNOWLEDGEMENT}

The cooperation of R. E. Brown and D. W. Rhodes, Radiological Sciences Department, W. G. Browne, J. J. Courtney, E. F. Curren, and L. W. Finch, Manufacturing Department, R. E. Burns and C. E.

- Michelson, Chemistry Unit, and members of their groups, in the completion and evaluation of this test, is appreciated.

$\circ$ MJS:ag

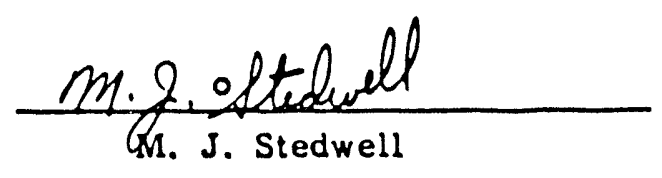




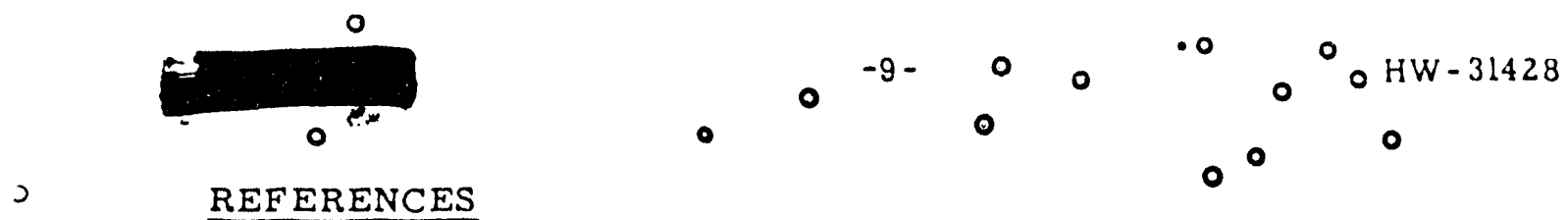

REFERENCES

- (1) HW-29383, PTest Procedure to Evaluate Scavenging of TBP Plant

0 Solvent Extraction Waste with Nickel Fergocyanide," J. G. Bradley.

(2) Letter to L. W. Finch, "Cribbing of Scavenged RAW", J. M. Smith,

0 November 16, 1953.

(3) HW-30652, "TBP Waste Disposal Criteria for Cribbing of Scavenged - RAW," H. V. Clukey.

(4) Analytical data obtalned from R. E. Burns, Applied Research SubSection, Chemistr9 Unit.

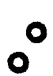

○

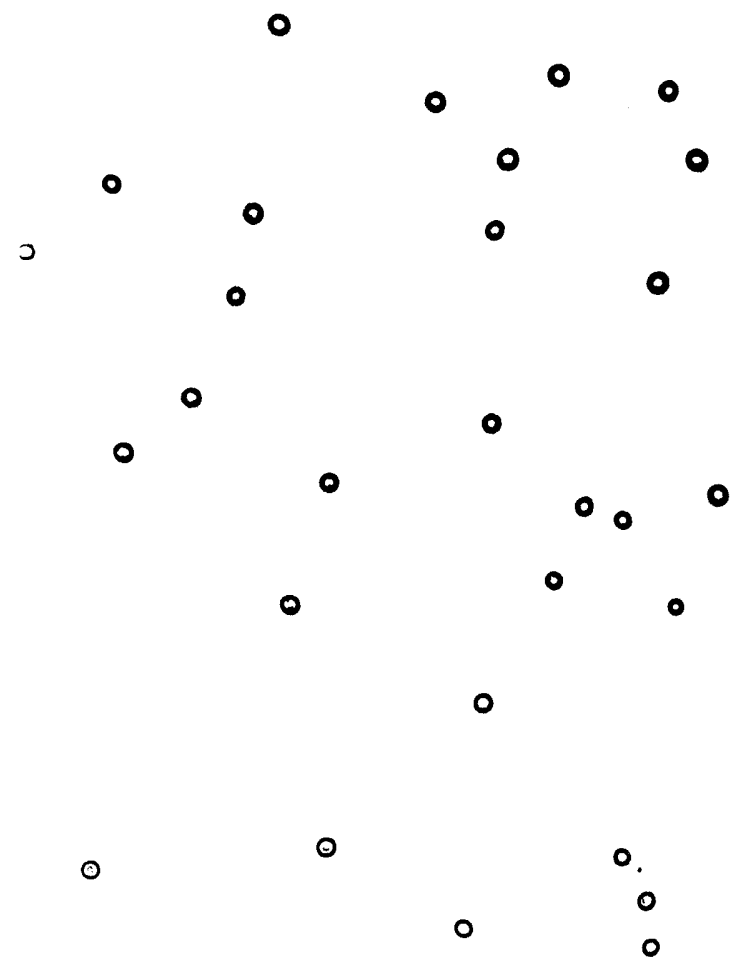

๑
๑.

o

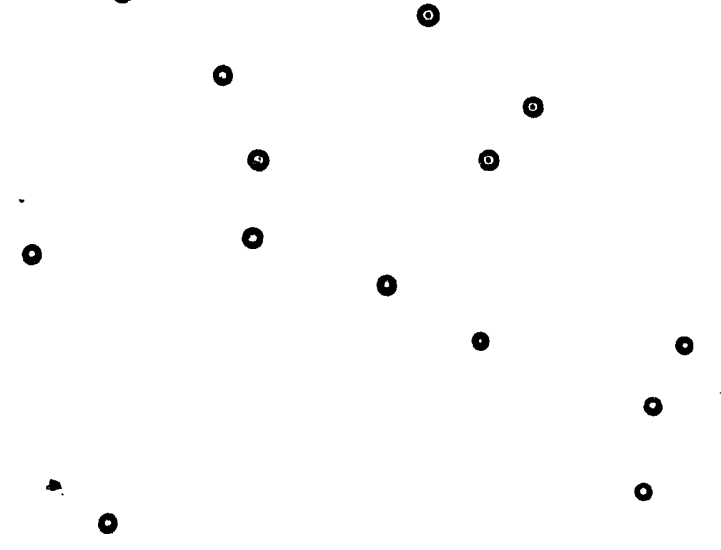

o

8

0 $00^{\circ}$ 
0

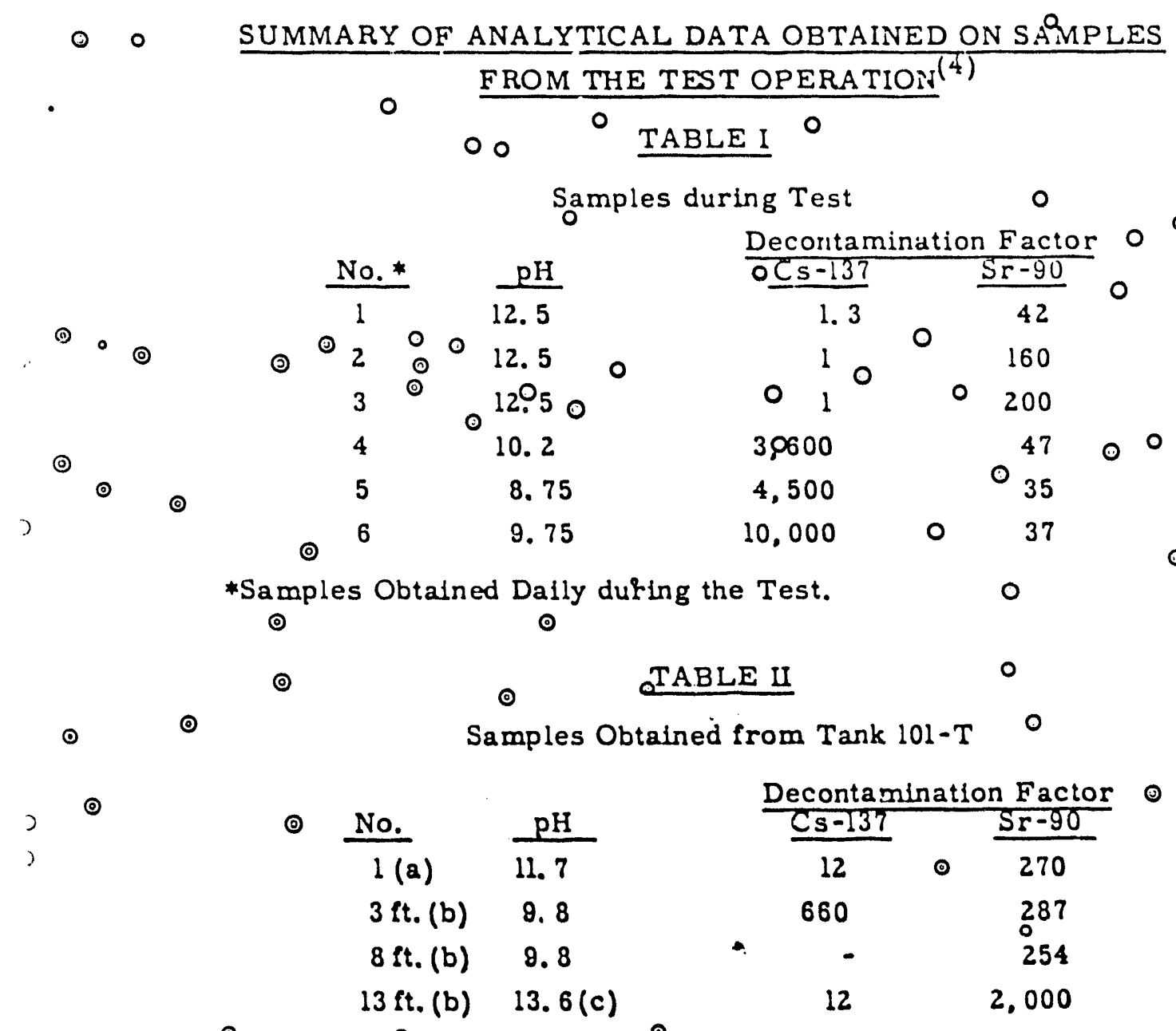

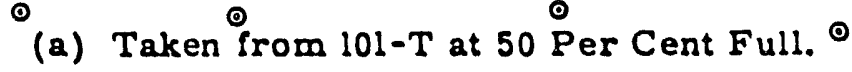

- (b) Taken from 101-T Three Days after Filling and before Complete Sludge Settling.

(๑) (c) Corrected for Sodium.

๑๑

$\odot$

$\circ$

$\odot$ $\circ$ $\circ$

(1) 


\section{TABLE WII}

Fifteen samples were obtained through the 12 -inch pump pit riser and 16 samples were obtained through the $1 \dot{z}$-inch sluice pit riser. Samples were obtained through each riser at one foot intervals from the surface of the liquid to the lower level. .

\begin{tabular}{|c|c|c|c|c|c|c|c|}
\hline \multirow[b]{2}{*}{ Sample Level* } & \multirow[b]{2}{*}{$\mathrm{pH}$} & \multirow[b]{2}{*}{$\begin{array}{c}\mathrm{Pu} \\
\mathrm{D} / \mathrm{m} / \mathrm{ml} .\end{array}$} & \multirow[b]{2}{*}{$\begin{array}{c}U \\
G / L \\
\end{array}$} & \multicolumn{4}{|c|}{ Decontamination Factor } \\
\hline & & & & Cs-137 & $5 r-90$ & $\begin{array}{c}\text { Gross } \\
\text { Gamma } \\
\end{array}$ & $\begin{array}{l}\text { Gross } \\
\circ \text { Beta } \\
\end{array}$ \\
\hline Surface to $8 \mathrm{ft}$. & 9.8 & 270 & 0.15 & 420 & 220 & 83 & 41 \\
\hline $9 \mathrm{ft}$. & 11.0 & 76 & 0.15 & 155 & 275 & 51 & 29 \\
\hline 10 to $15 \mathrm{ft}$. & 12. 0 & 14 & 0.05 & $6.0 *$ & $1460 *$ & 2.8 & ${ }_{0}^{3.1^{\circ}}$ \\
\hline
\end{tabular}

* Sample level expressed in feet below liquid surface.

** Sr-90 decontaminates better at higher pH values while the Cs-137 DF decreases.

$\mathrm{pH}$ values for satisfactory decontamination of both are 8 to 10 . $\quad$ -

\section{TABLE IV -}

Effluent samples from the Soll Column run of a sample obtained three feet below 101-T liquid surface.

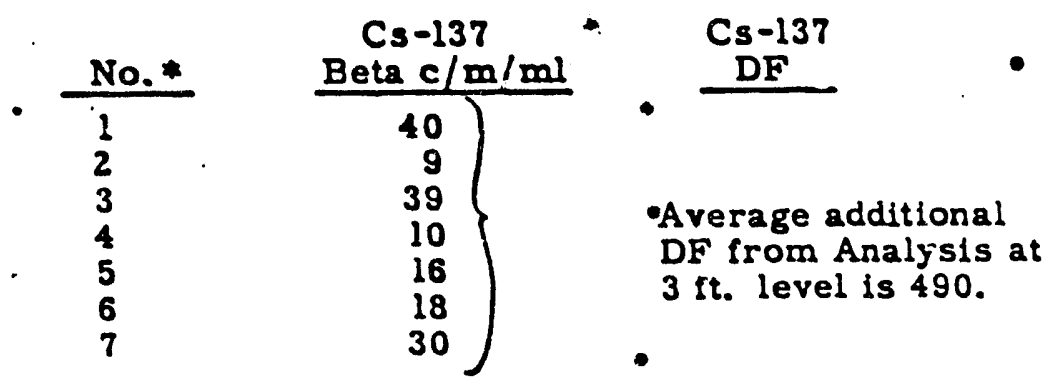

* Represents samples from three column volumes of effuent. 

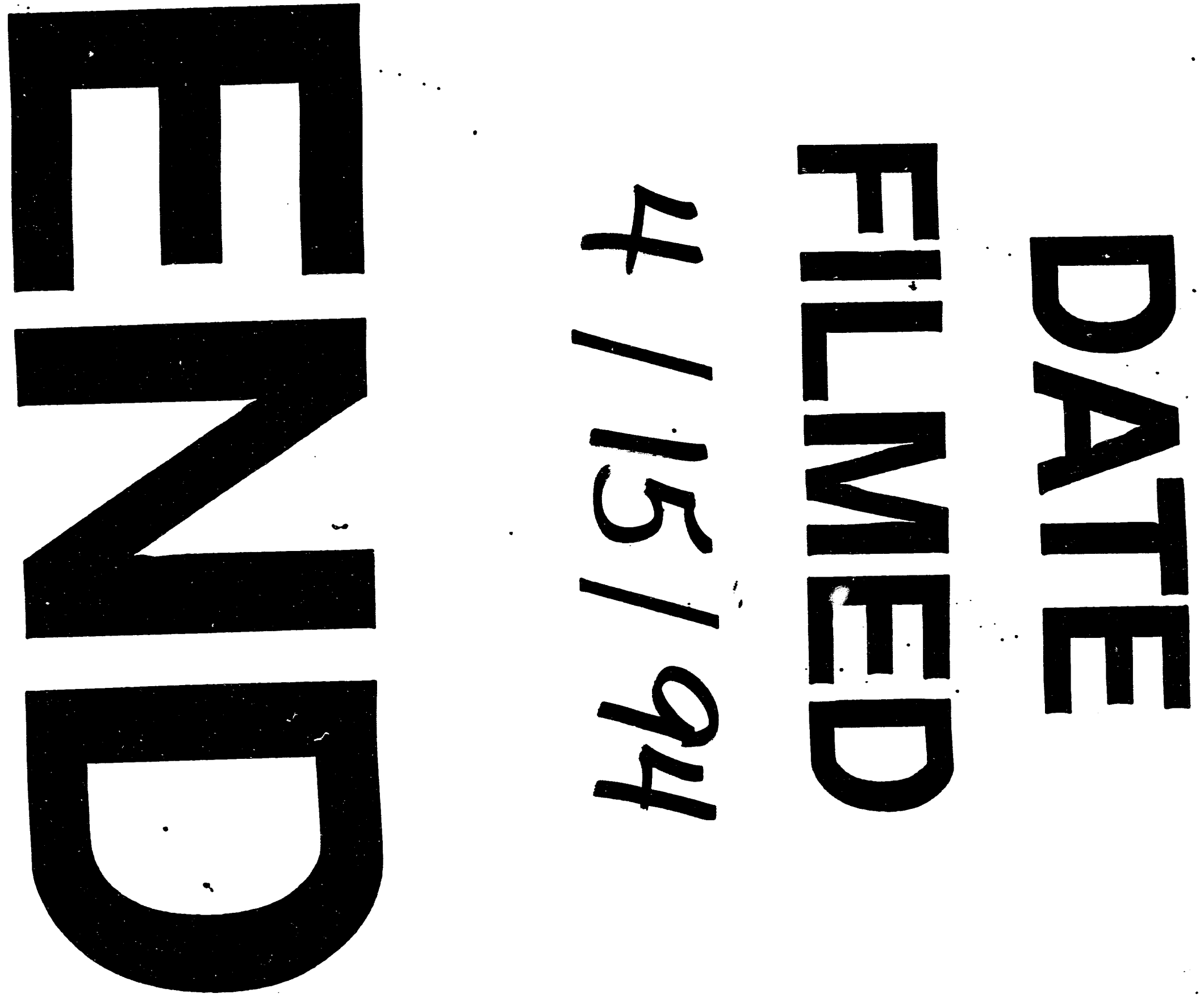


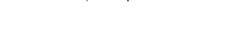

